\title{
DE WERKBESCHEIDEN VAN DE ACCOUNTANT
}

door H.J.Reijn

\section{Inleiding}

Tussen de vele onderwerpen, die in de vakbladen en op de vergaderingen van beroepsgenoten de aandacht genieten - en deze aandacht terecht genieten paraisseren als regel slechts weinig "technische” problemen van de uitoefening der accountantsarbeid. Toch ware het in het belang én van de beroepsuitoefening én van de studerenden in accountancy ook in voldoende mate aandacht te besteden aan de vraagstukken van bedoelde aard.

Pionierskarakter kan in dit opzicht worden toegekend aan de bekende artikelen van de heer G. Hartog over dossiers, aantekeningen, vastleggingen enz. ${ }^{1}$ ) Uiteraard zijn echter ook artikelen als die onderhevig aan ,,veroudering”. Daarnaast zijn voor de fase der beroepsontwikkeling, waarin deze thans in ons land verkeert, de vrijwel alleen descriptieve artikelen als de genoemde van de heer Hartog niet meer geheel toereikend. Daarnaast is het noodzakelijk geworden de „technische” werkwijzen principieel te funderen, daarmee een waarneembare brug slaande tussen de uitvoerende arbeid, verricht door of in opdracht van de accountant, en de principiële grondslagen van zijn beroep.

Een poging, een bijdrage te leveren, aangepast aan deze voortgaande ontwikkeling, is de doelstelling van dit artikel, handelende over de werkbescheiden van de accountant.

\section{Terminologie}

In de Nederlandse vakliteratuur is het gebruikelijk, de gezamenlijke bescheiden terzake van een door een accountant uitgevoerde opdracht aan te duiden als ,het dossier" omtrent de bedoelde opdracht. In feite is dit een weinigzeggende aanduiding. De Angelsaksische literatuur spreekt van „working papers", de Duitse literatuur van „Arbeitspapiere”, de Spaanse literatuur van „papeles de trabajo”. Deze woorden geven in aanmerkelijk duidelijker mate dan het woord "dossier" aan, welke bescheiden bedoeld worden. Het zou m.i. dan ook aanbeveling verdienen het woord "werkbescheiden" te gebruiken als aanduiding van de gezamenlijke bescheiden terzake van de uitvoering van een bepaalde opdracht. Werkbescheiden, die in één of meerdere dossiers (in de zin van: omslagmappen) worden gearchiveerd.

\section{Werkpapieren en werkbescheiden}

In de Engelse en Duitse literatuur wordt onderscheid gemaakt tussen ,audit working papers" resp. "Arbeitspapiere” (de gezamenlijke bescheiden) en "audit working sheets” resp. „Arbeitsbogen” (de afzonderlijke stukken). N.m.m. heeft dit onderscheid - in het Nederlands te vertalen als b.v. resp. werkbescheiden en werkpapieren - weinig of geen betekenis.

\section{Definities in de vakliteratuur}

Voor de formulering van een definitie van het begrip ,"werkbescheiden” biedt

1) in ,25 Jaren M.A.B.", deel II, pag. 413/452

m a b blz. 161 
de Nederlandse vakliteratuur weinig aanknopingspunten. Wel geeft deze uiterst nuttige wenken omtrent de indeling e.d. van de dossiers, waarin de werkbescheiden worden opgeborgen, doch aan de definiëring van wat er onder moet worden verstaan wordt slechts zeer beperkt aandacht besteed.

In de Amerikaanse literatuur komen verscheidene definities voor. De Corporation Audits Division van het General Accounting Office van de Verenigde Staten omschrijft de werkbescheiden kort als ,alle papieren waarop een accountant aantekening omtrent een onderzoek maakt". Een soortgelijke definitie geeft Peloubet ${ }^{2}$ ).

In navolging van de definities in de Amerikaanse literatuur - doch mede de van de cliënt of van derden door de accountant ontvangen bescheiden in zijn definitie opnemend - komt Hansjoachim Staks tor de omschrijving: „Arbeitspapiere sind alle diejenigen Papiere auf denen der Prüfer Tatsachen und Angaben aufgezeichnet hat, die eine Prüfung betreffen, sowie die Unterlagen die er von seinem Mandanten und von Dritten zur Ergänzung seiner Aufzeichnungen erhalten hat" 3 ).

Een eveneens zeer korte definitie geeft F. A. J. Couldery: „An accountant's working papers are the papers which the accountant finds it necessary or desirable to prepare in the course of carrying out his work" ${ }^{4}$ ).

De geciteerde omschrijvingen hebben gemeen, dat zij in de definitie de doelstelling van de aanleg der werkbescheiden niet aangeven. Naar mijn mening is zodanig opnemen der doelstelling in de definitie zelf uitermate wenselijk om daardoor tot een duidelijke begrenzing te geraken.

Teneinde tot de formulering van een zodanige definitie te geraken is het noodzakelijk de functie van de werkbescheiden aan een beschouwing te onderwerpen.

\section{Functie van de werkbescheiden}

De werkbescheiden van de accountant bedoelen iets tot stand te brengen, zij zijn gericht op een doel. Deze gerichtheid is zowel ",naar binnen” (de functie van de werkbescheiden binnen het accountantskantoor) als "naar buiten” (de functie van de werkbescheiden tegenover de professionele tuchtorganen).

\section{De interne gerichtheid van de werkbescheiden}

Bezien wij de normale gang van zaken bij controle ener jaarrekening in het kader van een doorlopende controle-opdracht.

In de loop van het jaar worden periodiek door de accountant en/of zijn assistenten werkzaamheden verricht, opmerkingen genoteerd en voorzover nodig cijfermatige en andere gegevens vastgelegd. $\mathrm{Na}$ afloop van het te controleren tijdvak worden de alsdan nog te verrichten werkzaamheden terzake van de administratie over het laatste deel van het jaar en terzake van de jaarstukken verricht.

De aard en omvang der vorenbedoelde werkzaamheden worden bepaald door het werkprogramma.

Wat is het werkprogramma?

Het werkprogramma is de - na bezinning op de aard van de opdracht en de

2) Peloubet "Audit working papers", New York, 1949

3) H. Staks "Die Anlage und Zweckmässigkeit von Arbeitspapieren”, Düsseldorf, 1955

4) Couldery "The accountant's working papers", London, 1960

$\mathrm{m}$ a b blz. 162 
omstandigheden waaronder ze moet worden uitgevoerd - door de accountant gemaakte beschrijving van de vastgestelde werkzaamheden welke in de concrete situatie moeten worden verricht om tot het door de opdracht gestelde (en door de accountant op rationaliteit beoordeelde en daarna aanvaarde) doel te geraken.

Dit werkprogramma dient de accountant n.m.m. te allen tijde schriftelijk vast te leggen. Daarvoor zijn o.a. als redenen te noemen dat het document de taakopdracht vormt voor de uitvoerders en dat de schriftelijke vastlegging de leidraad moet vormen voor de vaststelling door de accountant, dat hetgeen hij noodzakelijk achtte, is verricht. De doelmatigheid van deze vaststelling wordt bevorderd indien de werkbescheiden duidelijk het verband met het werkprogramma aangeven. Van ieder onderdeel van het werkprogramma dient een „onderliggend” stuk (denk aan het Duitse woord „Unterlage”!) aanwezig te zijn, dat de uitvoering aantoont en de bevindingen van de uitvoerder(s) vermeldt. Denkbaar is zelfs de documenten te nummeren in aansluiting aan de nummering van de onderdelen van het werkprogramma.

Volledigheidshalve zij opgemerkt, dat het werkprogramma voor een bepaalde opdracht kan verwijzen naar een Algemene Instructie. In dit verband worden gememoreerd de artikelen hieromtrent van de heren P. J. H. J. Bos ${ }^{5}$ ) en L. G. van der Hoek ${ }^{6}$ ).

Voorts is na voltooiing der werkzaamheden aanwezig de arbeidsregistratie (in beginsel omvattende de beschrijving der verrichte werkzaamheden en het bestede aantal uren), welke in artikel 3 van het Reglement van Arbeid is voorgeschreven.

Deze gezamenlijke documenten: werkprogramma, uitvoeringsbescheiden en arbeidsregistratie, tezamen de werkbescheiden vormende terzake van de onderhavige opdracht, worden aan de accountant voorgelegd, welke de volledigheid der taakuitvoering nagaat, de genoteerde opmerkingen doorneemt en zich aldus een oordeel vormt, of de verrichte arbeid een "deugdelijke grondslag” vormt. Daarna stelt hij zijn rapport samen.

Deze functie van de werkbescheiden: de accountant de gegevens te verschaffen voor de controle op de uitvoering van de door hem voorgeschreven werkzaamheden en voor zijn oordeelsvorming omtrent datgene waaromtrent van hem een oordeel wordt verwacht, is de interne functie van de werkbescheiden.

Zoals hiervoren gesteld, dient de accountant die een rapport ondertekent zélf kennis te hebben genomen van de werkbescheiden en dient hij zelf de toereikendheid der fundering van de in het rapport gestelde mening te hebben beoordeeld. Zulks geldt ook, als het onderzoek is geleid en het concept-rapport is opgesteld door een in dienst van de ondertekenaar werkzaam accountant. Naar mijn mening volgt deze opvatting rechtstreeks uit de volledige persoonlijke verantwoordelijkheid welke de ondertekenaar van een rapport aanvaardt door de ondertekening.

Uit Montgomery wordt ten deze geciteerd de volgende uitspraak van de S.E.C.: „Working papers prepared by staff accountants should be reviewed critically by a principal or qualified delegate. We think it is self-evident that the review upon which an accounting firm assumes responsibility for work done by sub-ordinates must be more than a series of perfunctory questions as to the performance of particular items in an audit program" en "The extent of the review should be

5) in „25 Jaren M.A.B.", deel II, pag. $453 / 463$

i) in "25 Jaren M.A.B.", deel II, pag. $464 / 474$

$\mathrm{m}$ a b blz. 163 
sufficient to determine that auditing procedures were adequate and permit an informed judgment as to the fairness and clarity of the financial statements".

De doelmatigheid van de werkbescheiden wordt bevorderd indien zij zowel ten aanzien van hun inrichting als hun inhoud zijn opgesteld overeenkomstig de in het betreffende onderdeel van het werkprogramma door de accountant tot uitdrukking gebrachte intenties. In de dossiers komen nog (te)veel documenten voor, welke voor de controle, oordeelsvorming en rapportering door de accountant geen betekenis hebben. De "bloempjes van Catharina de Grote" - de lezer zij herinnerd aan het door Prof. Dr. H. J. van der Schroeff ${ }^{7}$ ) hieromtrent gememoreerde - groeien en bloeien ook veelvuldig in de werkbescheiden van accountants. Ten dele is dit een gevolg van de bij assistenten soms te constateren gedachte, dat „te veel" beter is dan "te weinig", anderzijds wordt vaak te weinig aandacht aan beperkingsmogelijkheden besteed. Onnut bestede tijd is schadelijk voor opdrachtgever en accountant. Diepgaand contact tussen de accountant en zijn assistenten over de doelstelling van ieder onderdeel van een werkprogramma kan ter vermijding daarvan een belangrijke bijdrage leveren.

\section{De externe gerichtheid der werkbescheiden}

De werkbescheiden hebben ook een gerichtheid, ,naar buiten", n.l. naar de accountant om zijn integriteit als accountant te verdedigen" 8 ).

Indien een accountant - door toedoen van beroepsgenoten of derden - in de noodzaak komt te verkeren tegenover de tuchtorganen te bewijzen, dat door hem in een concrete situatie de arbeid is verricht op zodanige wijze, dat zij een deugdelijke grondslag vormde voor de door hem gedane mededelingen omtrent de uitkomst van zijn onderzoek, vormen de werkbescheiden, het programma van het onderzoek en de uitvoering daarvan tonend, zijn belangrijkste gegeven. De uit deskundige beroepsgenoten bestaande tuchtorganen kunnen daaruit vaststellen of de accountant bij taakbepaling en taakuitvoering deed wat hij naar professionele normen diende te doen. Ruiz de Valesco drukt dit zeer duidelijk uit door de opmerking, dat de werkbescheiden , het enige bewijsstuk zijn van de accountant om zijn integriteit als accountant te verdedigen" ${ }^{8}$ ).

\section{Van derden ontvangen bescheiden}

Tot de werkbescheiden behoren naast de door de accountant zelf opgestelde bescheiden ook die, welke hij zich door de cliënt of een derde (b.v. een bank) doet verstrekken. Deze bescheiden worden echter eerst werkbescheiden van de accountant door de verrichting van de vaktechnisch noodzakelijke werkzaamheden door de accountant ten aanzien van die bescheiden.

Een van een cliënt ontvangen lijst van openstaande vorderingen b.v. wordt eerst een wezenlijk onderdeel van de werkbescheiden van de accountant, doordat deze de op de lijst noodzakelijke controle verricht. Hetzelfde geldt voor de van derden ontvangen stukken. Een opgave van een bank van de bij haar voor een cliënt in bewaring zijnde effecten vormt eerst een onderdeel van de werkbescheiden door verrichting van de afstemming van de gegevens der administratie met de opgave van de bank.

7) o.a. in „Leiding en organisatie van het bedrijf”, pag. 137/138

8) in „Auditoria práctica”, Mexico, 1959 


\section{Ordelijkbeid der bescheiden}

De werkbescheiden van de accountant moeten zijn ordelijke bescheiden, d.w.z. bladen papier, waarop op ordelijke en overzichtelijke wijze gegevens zijn vermeld. Niet genoeg kan beklemtoond worden, dat het noodzakelijk is, dat de opstelling der werkbescheiden aan hoge eisen van ordelijkheid en duidelijkheid voldoet. Nimmer mag discutabel zijn wat het vermelde inhoudt, welke zekerheid omtrent het vermelde bestaat en hoe deze is verkregen. Gememoreerd zij in dit verband een uitspraak van de Raad van Tucht: „De accountant die van voor zijn onderzoek van belang zijnde gegevens zodanige klad-aantekeningen maakt, dat hij de betekenis daarvan achteraf niet meer kan vaststellen, handelt zorgeloos" ${ }^{9}$ ).

Voor wat betreft de van de cliënt ontvangen bescheiden - door deze uiteraard opgesteld in een vorm en indeling, welke aan de behoeften van de cliënt zijn aangepast - kan het noodzakelijk zijn ze - teneinde voor de behoefte van de accountant benodigde staten te verkrijgen - om te werken.

\section{Definitie}

Op basis van de vorenstaande beschouwingen kunnen concluderend m.i. de werkbescheiden als volgt worden omschreven:

De werkbescheiden van de accountant terzake van een door hem uitgevoerde opdracht zijn de bescheiden, welke de accountant noodzakelijkerwijze opstelt resp. zich doet verstrekken als grondslag voor zijn oordeelsvorming en rapportering en als bewijsstuk voor de deugdelijke uitvoering van de uit de opdracht voortvloeiende taak.

\section{Wijze van opberging en ordening}

Het ligt niet in de opzet van dit artikel, de wijze van opberging en ordening der werkbescheiden te bespreken. M.i. is geen methode aan te geven, die voor alle concrete gevallen als de meest wenselijke moet worden aangemerkt. De artikelen van de heer G. Hartog en in de Bedrijfseconomische Encyclopedie geven te dezer zake nuttige suggesties. Welk systeem gevolgd wordt is ook niet zo belangrijk. Hoofdzaak is: ordelijkheid en een aan de omstandigheden aangepaste systematiek.

\section{Eigendom van de werkbescheiden en gebeimbouding}

Uit het hiervorenstaande betoog omtrent de functie der werkbescheiden volgt m.i. zonder meer, dat de werkbescheiden van de accountant eigendom van de accountant zijn, waarover hij uiteraard met de grootst mogelijke zorgvuldigheid en kiesheid dient te beschikken. Deze mening wordt ook in de Amerikaanse, Engelse en Duitse vakliteratuur gehuldigd.

Hiermee verband houdt het vraagstuk van het beroepsgeheim van de accountant. Hoewel dit vraagstuk hier niet kan worden behandeld, verdient het aanbeveling toch enkele korte opmerkingen te maken.

De accountant behoort tot de ,,gepatenteerde geheimhouders". Zijn beroepsgeheim volgt uit de aard van zijn beroep, is rechtstreeks gevolg van de vertrouwensverhouding tussen cliënt en accountant. Dit beroepsgeheim strekt zich mede uit over zijn dossiers ${ }^{10}$ ).

9) Raad van Tucht, 1958-2

10) Zie Mr. D. Hazewinkel-Suringa „De doolhof van het beroepsgeheim”, Haarlem, 1959, en L. van Essen Lzn. „Het beroepsgeheim, in het bijzonder dat van de accountant” (Accountantsdag 1946) 
M.i. geldt dit echter niet tegenover de professionele tuchtorganen en moet de accountant aan deze organen zijn werkbescheiden zonder enige beperking overleggen. Het algemeen belang, dat gediend wordt door de arbeid van de tuchtorganen vormt hiervoor m.i. een meer dan voldoende rechtvaardiging. Uiteraard is ook aan het lidmaatschap van deze tuchtorganen het beroepsgeheim inhaerent. 